\title{
A Near Electoral Majority of Pensioners: Prospects and Policies
}

\author{
Warren C. Sanderson and Sergei Scherbov \\ International Institute for Applied Systems Analysis, Laxenburg, Austria
}

RP-07-003

September 2007

Reprinted from Population and Development Review 33(3): 543-554 (September 2007) 
IIASA Reprints make research conducted at the International Institute for Applied Systems Analysis more accessible to a wider audience. They reprint independently reviewed articles that have been previously published in journals. Views or opinions expressed herein do not necessarily represent those of the Institute, its National Member Organizations, or other organizations supporting the work.

Reprinted with permission from Population and Development Review 33(3): 543-554 (September 2007)

Copyright () 2007

All rights reserved. No part of this publication may be reproduced or transmitted in any form or by any means, electronic or mechanical, including photocopy, recording, or any information storage or retrieval system, without permission in writing from the copyright holder. 


\title{
A Near Electoral Majority of Pensioners: Prospects and Policies
}

\author{
WARREN C. SANDERSON \\ SERGEI SCHERBov
}

EVIDENCE FROM A variety of sources indicates that the age structure of a population influences the allocation of public spending. Countries with older populations generally spend more on social programs, particularly on those that help the elderly. McDonald and Budge (2005), using data from 21 democracies, found that the proportion of the population aged 65 and older had a strong positive influence on government social spending in the 1990 s after controlling for the ideology of the political party in power.

Disney (2007), using data from 21 OECD countries from the 1970s through the 1990s, showed that the size of the welfare state was positively related to the relative size of the population 65 and older. He did not control for political factors, but did control for economic factors that could have had an effect on the size of the welfare state. MacManus (1995) found suggestions in US public opinion poll data that older generations would increasingly push for greater government spending, especially on programs helping them. Poterba (1998) showed that educational expenditures per child decreased significantly in the United States as the proportion of the elderly in school districts increased. Preston (1984), using data from the United States, was one of the earliest to demonstrate the relationship between age structure changes and the allocation of public funds to programs affecting the young and the elderly.

The aging of voting age populations does not imply that voters will shift their party preferences. Rather, as shown in McDonald and Budge (2005), the allocation of public spending depends both on the ideology of the political parties in power and on the age structure. In the long run, political parties, in their competition for votes, respond to the concerns of the electorate. Aging is now rapidly changing those concerns. A good example is the recent legislation in the United States that provides a prescription drug benefit to people 65 and older. This legislation was proposed by a Republican president 
and passed by two houses of Congress, both controlled by Republicans, even though the Republican Party has traditionally favored less public spending on social programs.

In the first half of the twenty-first century in many of today's more developed countries, the proportion of voting age populations aged 65 and older will roughly double. As voting age populations age, the proportion of net contributors to national budgets (mainly through taxes) will fall and the proportion of net beneficiaries (mainly through pension and health care benefits) will rise. Even ignoring health care expenditures, an unprecedented situation could arise in many countries in which the number of voters receiving net monetary contributions from the government would be close to or outnumber the number of voters making net monetary contributions to it. This is political terra incognita.

In this note, we take three steps toward understanding the demography of this new political environment. We do this by considering the cases of Germany, Japan, and the United States. These three countries span almost the entire range of aging experiences to be expected in the coming decades in today's industrialized countries. In the next section we investigate the effects of changes in normal pension ages ${ }^{1}$ on the proportions of voting age populations receiving public pensions and on the waiting time from the median age of that population to the receipt of a public pension. We show that intergenerationally equitable increases in pension ages could reduce the proportions of voting age populations receiving public pensions in Germany, Japan, and the United States by 10-20 percent. Even in the case of an intergenerationally equitable increase in the pension age, around 40 percent of Japan's voting age population would be receiving a public pension in 2050. Without such an increase in pension age, the corresponding figure would be around 46 percent. Of course, public pensions are not the only source of support for retired people. Private pensions and other forms of savings are also important.

We focus here on public pensions because voting behavior can influence them more directly than other sources of old-age support. In some European countries new public pension arrangements have been introduced, called notional defined contribution plans, that mimic some aspects of fully funded accounts (Holtzmann and Palmer 2006). Typically, these plans retain the pay-as-you-go aspect of the financing of public pensions while providing benefits according to schedules that are more akin to those found in fully funded accounts. Regardless of which type of account we are considering, the problem of having a large proportion of the electorate receiving a public pension remains, because voters can always change the parameters of any public pension system.

There are, of course, two ways of reducing the proportion of the voting age population who are receiving a public pension or are close to receiving one. We first consider increases in the normal age for the receipt of a public 
pension. We then investigate the effects of lowering the voting age. We do this by examining an extreme voting age reform, one that allows parents to vote in place of their not-yet-enfranchised children. This reform has been widely discussed in Germany's political debate and has been formally discussed in the German parliament (Deutscher Bundestag 2004). We analyze it here not because it is politically feasible, but because the calculations provide an illustrative upper bound on the effects of voting age reform.

Large proportions of voting age populations in developed countries in the future will either be receiving public pensions or be expecting to receive one within the next few years. In view of this, it is of interest to ask about the remaining years of life expectancy of future voters. If life expectancy shortens as voting age populations age, voters may be less concerned with the long-run viability of their public pension systems. We show that the life expectancy of median-aged members of the voting age populations of Germany, Japan, and the United States will change only modestly from 2000 to 2050.

\section{The effects of pension age reforms}

In Germany, Japan, and the United States, as in many other developed countries, either normal pension ages are already increasing (United States Social Security Administration 2004) or legislation is in place (Foreign Press Center Japan, n.d.; Sakamoto 2005; United States Social Security Administration 2007) to increase them in the future. ${ }^{2}$

In a standard public pension system that is fully indexed to inflation, it is possible to establish bounds on intergenerationally equitable changes in the public pension age when life expectancies increase. At one extreme is the no-reform option (Option 1), where the normal pension age remains as it was in 2000. This option is not intergenerationally equitable because members of each successive generation contribute the same proportion of their incomes during their working years and receive, on average, ever longer benefit streams as their life expectancies increase. At the other extreme, we consider an increase in the normal pension age such that the average number of years of pension receipt remains fixed and all increases in life expectancy lengthen the time before a pension can be received (Option 3). Option 3 is also not intergenerationally equitable. Successive generations pay ever more into the pension systems because of increases in life expectancies, only to receive benefits over a period that is on average of constant length.

Intergenerationally equitable changes in the normal public pension age must fall between Option 1 and Option 3. In Option 2, the normal pension age is taken as the average of the ages in Options 1 and 3, and the option provides us with an estimate of an intergenerationally equitable change in pension age. In Option 2, workers finance a portion of their additional years of pension with additional years of pension contribution. Option 2 corresponds roughly to an 
increase in the pension age by one month per year, Option 3 to an increase in the pension age by two months per year (Sanderson and Scherbov 2005).

The current voting age in Germany and the United States is 18. In Japan, it is 20. In our calculations, we assume that these ages do not change. Normal pension ages in 2000 are assumed to be 65 years in all three countries.

The population forecasts used here are a deterministic version of the probabilistic forecasts in Sanderson and Scherbov (2005) using the mean scenario. Values of the total fertility rate and life expectancy at birth (both sexes) are as follows:

\begin{tabular}{|c|c|c|c|c|c|c|}
\hline \multirow[b]{2}{*}{ Year } & \multicolumn{2}{|c|}{ Germany } & \multicolumn{2}{|c|}{ Japan } & \multicolumn{2}{|c|}{ United States } \\
\hline & TFR & $\mathbf{e}_{0}$ & TFR & $\mathbf{e}_{0}$ & TFR & $\mathrm{e}_{0}$ \\
\hline 2000 & 1.4 & 77.7 & 1.4 & 81.1 & 2.1 & 76.9 \\
\hline 2025 & 1.4 & 82.8 & 1.4 & 86.2 & 2.0 & 81.8 \\
\hline 2050 & 1.5 & 87.9 & 1.5 & 91.3 & 1.9 & 86.9 \\
\hline
\end{tabular}

Table 1 shows the percentages of voting age populations at or above the normal pension ages for each of the three options. By 2050, adopting Option 2 causes the percentage of people of pension age in the voting age population to fall by 7 percentage points in Germany, from 39 (under Option 1) to 32 percent, by 6 percentage points in Japan, from 46 to 40 percent, and by 5 percentage points in the United States, from 29 to 24 percent. Note, however, that even with this pension age reform, the percentage of the voting age population at or above the normal pension age in Japan almost doubles from 2000 to 2050 .

Table 2 provides a different perspective on the effects of pension age reform. By 2050, without further changes in the normal pension age, a majority of the Japanese voting age population would be either receiving a pension or

TABLE I Percentage of voting age population at or above the normal pension age under three options, (1) no change in normal pension age, (2) normal pension age increases one month per year, and (3) normal pension age increases two months per year: Germany, Japan, and the United States 2000-50

\begin{tabular}{|c|c|c|c|c|c|c|c|c|c|}
\hline \multirow[b]{2}{*}{ Year } & \multicolumn{3}{|c|}{ Germany } & \multicolumn{3}{|l|}{ Japan } & \multicolumn{3}{|c|}{ United States } \\
\hline & Opt. 1 & Opt. 2 & Opt. 3 & Opt. I & Opt. 2 & Opt. 3 & Opt. 1 & Opt. 2 & Opt. 3 \\
\hline 2000 & 20.1 & 20.1 & 20.1 & 21.7 & 21.7 & 21.7 & 16.6 & 16.6 & 16.6 \\
\hline 2010 & 24.4 & 23.3 & 22.1 & 27.5 & 26.3 & 25.0 & 16.9 & 16.2 & 15.4 \\
\hline 2020 & 26.7 & 24.1 & 21.6 & 34.1 & 31.9 & 29.5 & 20.9 & 18.9 & 17.0 \\
\hline 2030 & 32.8 & 27.8 & 23.2 & 36.6 & 33.0 & 29.7 & 25.7 & 22.7 & 19.8 \\
\hline 2040 & 37.0 & 32.4 & 26.8 & 42.2 & 36.1 & 30.4 & 27.4 & 24.0 & 20.5 \\
\hline 2050 & 38.6 & 32.3 & 26.4 & 46.4 & 40.2 & 33.6 & 28.5 & 23.9 & 19.5 \\
\hline
\end{tabular}

NOTE: See text for further discussion of options.

SOURCE: Figures are computed from the mean scenario in Sanderson and Scherbov (2005). 
TABLE 2 Waiting time (in years) from median age of voting age population to normal pension age under three options, (1) no change in normal pension age, (2) normal pension age increases one month per year, and (3) normal pension age increases two months per year: Germany, Japan, and the United States 2000-50

\begin{tabular}{|c|c|c|c|c|c|c|c|c|c|}
\hline \multirow[b]{2}{*}{ Year } & \multicolumn{3}{|c|}{ Germany } & \multicolumn{3}{|l|}{ Japan } & \multicolumn{3}{|c|}{ United States } \\
\hline & Opt. I & Opt. 2 & Opt. 3 & Opt. I & Opt. 2 & Opt. 3 & Opt. 1 & Opt. 2 & Opt. 3 \\
\hline 2000 & 18.8 & 20.5 & 22.6 & 15.8 & 17.2 & 18.8 & 21.7 & 23.3 & 25.1 \\
\hline 2010 & 16.2 & 18.7 & 21.6 & 13.2 & 15.1 & 17.4 & 19.4 & 21.6 & 24.1 \\
\hline 2020 & 12.5 & 15.5 & 19.1 & 10.8 & 13.4 & 16.4 & 18.0 & 20.8 & 24.1 \\
\hline 2030 & 10.2 & 13.9 & 18.4 & 7.8 & 11.0 & 14.8 & 16.9 & 20.4 & 24.6 \\
\hline 2040 & 8.9 & 13.4 & 18.9 & 4.5 & 8.3 & 12.8 & 15.6 & 19.8 & 24.8 \\
\hline 2050 & 7.3 & 12.5 & 18.9 & 2.4 & 6.9 & 12.3 & 14.5 & 19.4 & 25.3 \\
\hline
\end{tabular}

NOTE: See text for further discussion of options.

SOURCE: Figures are computed from the mean scenario in Sanderson and Scherbov (2005).

within 2.4 years of doing so, assuming that no one receives an early public pension for disability or other reasons. Allowing for early pensions, it is clear that more than half of Japan's voting age population could be net beneficiaries of government expenditures some time around mid-century. Under Option 2, a majority of the Japanese voting age population in 2050 will be either above the normal pension age or within 6.9 years of receiving a public pension, again not allowing for any early pension recipients.

Without further increases in the normal pension age, a majority of the German voting age population in 2050 would be either receiving a public pension or within 7.3 years of receiving one, again not taking early pensions into account. Early pensions have been popular in Germany and if they are not curtailed, Germany could, like Japan, have a majority of its voting age population as net beneficiaries of government expenditures around mid-century. Assuming Option 2, a majority of the German voting age population would either be above the normal pension age or within 12.5 years of it.

The normal pension age is already increasing in the United States roughly in line with Option 2, although additional legislation would be needed to continue the pension age increases in the future. In 2000, a majority of the US voting age population was above the normal pension age or within 21.7 years of it. Under Option 2, that would change only marginally. The interaction between aging and politics is likely to be much less of a problem in the United States than in other developed democracies. This is consistent with Bergstrom and Hartman's (2005) demonstration of the political feasibility in the United States of a policy of increasing the normal pension age by oneeighth of a year per calendar year. This implied path of normal pension ages would be roughly halfway between our Options 2 and 3.

Pension age reforms, while useful for the sustainability of pension systems, will not, by themselves, prevent significant increases in the proportion 
of voting age populations who are net beneficiaries of government expenditures, especially in countries like Germany and Japan. Pension reforms, which do not include raising the normal pension age, can also be useful in maintaining the stability of pension systems, but they do not address the political problem of electoral majorities voting on their own pension levels.

\section{Voting age reform: Demeny voting}

In addition to increasing the normal pension age, proportions of voting age populations receiving or being close to receiving a public pension can be reduced by lowering the voting age. There are many possible reforms of voting age regulations. Here we consider a radical proposal, giving parents the right to vote as proxies for their children who are too young to vote themselves. We call this "Demeny voting," after Paul Demeny who suggested it (Demeny 1986). Demeny voting has recently been under active discussion in Germany (Deutscher Bundestag 2004; Weimann 2002). It is of interest to us here primarily because it is an extreme case of voting age reform. Politically feasible forms of voting age reform will have much less impact.

Demeny voting requires that we redefine the voting age population as the population at or above the legal minimum age for voting weighted by the factor one plus the number of children in each person's custody. For simplicity, we can think of women voting for all their underage female children and men for their underage male children.

As can be seen from Table 3, Demeny voting in Germany with no future changes in the normal pension age would result in the proportion of the Demeny voting age population at or above the normal pension age in 2050 of 33.1 percent. In the absence of Demeny voting, the proportion of the voting age population in that age group would be 38.6 percent (see Table 1 ). In 2000 (without Demeny voting), the proportion was 20.1 percent. For such an extreme voting age reform, the change in the proportion at or above the normal pension age of only 5.5 percentage points may seem small: it reflects the prevailing low fertility, hence the low proportion of the population below the normal voting age. Indeed, more modest reforms would have even more modest results.

Demeny voting in Germany combined with Option 2 with respect to the pension age reform would result in the percentage of the Demeny voting age population at or above the normal pension age rising to around 28 percent by 2040 and then stabilizing. This combination of policies could simultaneously serve a number of purposes. The increase in the normal pension age would help make the pension system sustainable and decrease the proportion of possible votes cast by those at or above the normal pension age. Further, Demeny voting could be one among a set of policies aimed at supporting 
TABLE 3 Percentage of voting age population above normal pension age in $\mathbf{2 0 0 0}$, and percentage of total population above normal pension age with Demeny voting under three options, (1) no change in normal pension age, (2) normal pension age increases one month per year, and (3) normal pension age increases two months per year: Germany, Japan, and the United States $2010-50$

\begin{tabular}{|c|c|c|c|c|c|c|c|c|c|}
\hline \multirow[b]{2}{*}{ Year } & \multicolumn{9}{|c|}{ Percentage of voting age population above normal pension age } \\
\hline & \multicolumn{3}{|c|}{ Germany } & \multicolumn{3}{|l|}{ Japan } & \multicolumn{3}{|c|}{ United States } \\
\hline \multirow[t]{4}{*}{2000} & 20.1 & & & 21.7 & & & 16.6 & & \\
\hline & \multicolumn{9}{|c|}{ Percentage of total population above normal pension age with Demeny voting } \\
\hline & \multicolumn{3}{|c|}{ Germany } & \multicolumn{3}{|l|}{ Japan } & \multicolumn{3}{|c|}{ United States } \\
\hline & Opt. 1 & Opt. 2 & Opt. 3 & Opt. 1 & Opt. 2 & Opt. 3 & Opt. 1 & Opt. 2 & Opt. 3 \\
\hline 2010 & 20.4 & 19.5 & 18.5 & 22.4 & 21.4 & 20.4 & 12.8 & 12.2 & 11.7 \\
\hline 2020 & 22.6 & 20.4 & 18.2 & 28.4 & 26.5 & 24.5 & 16.1 & 14.5 & 13.1 \\
\hline 2030 & 27.8 & 23.6 & 19.7 & 31.1 & 28.1 & 25.2 & 20.0 & 17.6 & 15.4 \\
\hline 2040 & 31.7 & 27.8 & 23.0 & 36.0 & 30.8 & 26.0 & 21.5 & 18.9 & 16.1 \\
\hline 2050 & 33.1 & 27.7 & 22.7 & 39.8 & 34.5 & 28.9 & 22.6 & 18.9 & 15.4 \\
\hline
\end{tabular}

NOTES: Figures for 2000 do not take Demeny voting into account. Calculation treats the total population as if it were the Demeny voting age population. This is a close approximation, but it does produce a slight downward bias in the percentages, especially for Japan under Option 1. This is consistent with our interpretation of the Demeny voting results as showing the maximum possible effect of a voting age reform. See text for further discussion of options.

SOURCE: Figures are computed from the mean scenario in Sanderson and Scherbov (2005).

higher fertility. (Feedback arising from this source is not taken into account in our calculations on the effects of voting reform: they reflect only the TFR assumptions specified in the text table on page 546.)

The situation in Japan is similar. Adding Demeny voting to Option 2 would reduce the percentage at or above the normal pension age in 2050 from 40.2 to 34.5 percent. Without both changes it would be 46.4 percent. Changing the normal pension age by about one month per year has roughly the same effect on the percent of the voting age population at or above the normal pension age in 2050 as allowing parents to vote for all their not-yetenfranchised children.

In the United States, increases in the normal pension age already being applied roughly follow Option 2 through 2027. If the United States continues on that path, around 23.9 percent of the voting age population will be at or above the normal pension age in 2050, up from 17 percent in 2000. If Demeny voting is added to the mix, the percentage rises only to 18.9 percent at mid-century.

More politically feasible voting age reforms, such as reducing voting ages by two years, would have only marginal effects on the proportions of the voting age population above or near the normal pension age. Indeed, even with Demeny voting, without further reforms in the age of pension receipt, the proportion of Japan's voting age population receiving a public pension would increase by around 65 percent between 2000 and 2050 . 


\section{Median life expectancies of voting age populations}

The life expectancies of voters could influence how they evaluate the desirability of policies with long-run payoffs compared with those having shortterm payoffs. In an era of increasing life expectancies, people of any particular age in the future will have longer remaining life expectancies than people of the same age today. The change in life expectancy of the median-aged person in the voting age population depends on how fast the median age changes over time compared with how fast remaining life expectancy increases.

Of course, most people do not know their life expectancies; nevertheless, they plan for their future. In doing so, they get information from a wide variety of sources including financial advisors, their doctors, the media, and their own observations. On average, all of these inputs would lead adults of any given age to make their plans about the future on the basis of longer time horizons than people of the same age a generation earlier. Evidence shows that the subjective probabilities of survival used in making those future plans (1) are consistent with life table probabilities when they are aggregated by age (Hurd and McGarry 1995), (2) change as predicted with new health information (Hurd and McGarry 2002), and (3) are associated as expected with patterns of saving and consumption (Salm 2006).

In order to provide an indicator of life expectancy that can be compared with a population's median age, Table 4 shows the age of an individual in the year 2000 who has the same remaining life expectancy as a person at the median age of the voting age populations of Germany, Japan, and the United States in the years 2010-50. This type of age measure was first introduced in Sanderson and Scherbov (2005) and is robust to whether it is measured using period or cohort life tables (Sanderson and Scherbov 2007).

We forecast the median age of a member of Germany's voting age population in 2050 to be around 58. Because of increases in life expectancy, he or she will have the same life expectancy as a 48-year-old German in 2000. Since the median-aged member of Germany's voting age population was 46 years in 2000, the life expectancy of Germany's median-aged voting age population member will barely budge during the first half of the century. Most of the increase in the median age of Germany's voting age population is likely to be offset by an increase in life expectancy.

Japan's voting age population will age faster than Germany's, but still increases in life expectancy are expected to offset the better part of the increase in the median age of the country's voting age population. The voting age population in the United States will age more slowly, and life expectancy increase will probably outpace it. An individual at the median age of the US voting age population in 2050 will have the same life expectancy as a 42 -yearold in 2000, which is slightly less than the observed median age of the voting age population in that year. Generally speaking, because life expectancy 
TABLE 4 Median age of voting age population and age of a person in 2000 who would have the same life expectancy as a person at the median age in the specified year: Germany, Japan, and United States, ten-year intervals 2000-50

\begin{tabular}{|c|c|c|c|c|c|c|}
\hline \multirow[b]{2}{*}{ Year } & \multicolumn{2}{|l|}{ Germany } & \multicolumn{2}{|l|}{ Japan } & \multicolumn{2}{|c|}{ United States } \\
\hline & $\begin{array}{l}\text { Median } \\
\text { age of } \\
\text { voting age } \\
\text { population }\end{array}$ & $\begin{array}{l}\text { Age of a person in } 2000 \\
\text { who would have the same } \\
\text { life expectancy as a person } \\
\text { at the median age of the } \\
\text { voting age population }\end{array}$ & $\begin{array}{l}\text { Median } \\
\text { age of } \\
\text { voting age } \\
\text { population }\end{array}$ & $\begin{array}{l}\text { Age of a person in } 2000 \\
\text { who would have the same } \\
\text { life expectancy as a person } \\
\text { at the median age of the } \\
\text { voting age population }\end{array}$ & $\begin{array}{l}\text { Median } \\
\text { age of } \\
\text { voting age } \\
\text { population }\end{array}$ & $\begin{array}{l}\text { Age of a person in } 2000 \\
\text { who would have the same } \\
\text { life expectancy as a person } \\
\text { at the median age of the } \\
\text { voting age population }\end{array}$ \\
\hline 2000 & 46.2 & 46.2 & 49.2 & 49.2 & 43.3 & 43.3 \\
\hline 2010 & 48.8 & 46.8 & 51.8 & 49.9 & 45.6 & 44.0 \\
\hline 2020 & 52.5 & 48.6 & 54.2 & 50.5 & 47.1 & 43.7 \\
\hline 2025 & 54.2 & 49.3 & 55.5 & 51.0 & 47.5 & 43.2 \\
\hline 2030 & 54.9 & 49.0 & 57.2 & 51.8 & 48.1 & 43.0 \\
\hline 2040 & 56.1 & 48.5 & 60.5 & 53.5 & 49.2 & 42.6 \\
\hline 2050 & 57.7 & 48.2 & 62.6 & 53.7 & 50.5 & 41.7 \\
\hline
\end{tabular}

NOTE: All figures are for both sexes combined.

SOURCE: Figures are median values computed over 1,000 probabilistic forecasts. See Sanderson and Scherbov (2005) and Lutz, Sanderson, and Scherbov (2001). 
increases in most developed countries are likely to be similar in magnitude to anticipated increases in the median ages of voting age populations, life expectancies at those median ages are not forecasted to change much during the period up to 2050 . To the extent that interest in policies with longer-term payoffs is influenced by those life expectancies, we would not expect the interest in those policies to change much either. In particular, even with large increases in proportions of voting age populations receiving or being close to receiving a public pension, we would not expect interest in a sustainable public pension system to diminish.

\section{Discussion}

The voting age population and the voting population are not the same. They differ for two main reasons. First, age-specific voting participation rates differ. Typically, younger people vote less often than older people. Second, some people in the population are not citizens and therefore not eligible to vote. In the United States, the median age of voters in the 2004 presidential election was about 3.5 years older than the median age of the voting age population (US Census Bureau 2006). In national elections around 2000 in Japan, the difference was similar (AARP Global Aging Program, n.d.). In Germany the difference was about two years (Statistisches Bundesamt Deutschland 2003). It is not clear whether these differences will persist or how they might change. If the median age of Japanese voters remained around 3.5 years higher than the median age of the voting age population, then the median age of Japanese voters in 2050 would be close to 65 . In the short run, at least, we would expect that the median voter would remain a few years older than the median member of the voting age population.

We do not think that it is in the interest of pensioners to block all public pension reforms. Pensioners and the young are natural allies on the issue of raising the normal pension age. Pensioners have an interest in raising the pension age for others, because it leaves more money available for themselves and because it lowers pressure to reduce their benefits. Raising the normal pension age would mean lower taxes for the working-age population. This is also in the interest of pensioners, with their long life expectancies, because it is not in their interest to raise taxes on workers to unsustainable levels. Therefore, in some countries it might be easier to pass pension age reform when the voting age population is much older than it is now rather than in the near term when a substantial fraction of the voting age population would be looking forward to soon receiving a public pension. Still, by that time, it might be rather late for pension age reform to help maintain the sustainability of the pension system itself.

As we move toward mid-century, we will be entering new political terrain. Without further reforms, some wealthier countries are likely to have 
a majority or near majority of their electorates receiving public pensions by 2050. Crucial steps to reduce potential future problems could be much easier to take now than they will be in a few decades (Sinn and Uebelmesser 2003; Uebelmesser 2004). Demographic analysis has an important role to play here both by showing what our future is likely to be in the absence of additional reforms and by quantifying the effects of our policy options.

\section{Notes}

The authors acknowledge the helpful comments made by members of the Political Science Department, Stony Brook University.

1 Normal pension age refers to the statutory age at which a full pension would normally be received. It is not the age at which an early reduced pension could be received, the age at which a disability pension could be received, the age at which a bereavement pension could be received, or the age at which any other special category of pensions could be received.

2 In March 2007 the German Bundestag passed legislation increasing the normal pension age gradually from age 65 to age 67 over a period of 18 years beginning in 2012. During the first 12 years, the normal pension age is to increase by one month per year. During the next six years, it is to increase by two months per year. Japan has a two-tiered pension system, with a national pension covering everyone in the country and a separate tier based on a person's type of employment. The normal pension age in the national system is 65. Reforms in 2004 stipulate that the normal pension age for an employee's pension is to rise gradually from 60 to 65 by 2025 for men and by 2030 for women. In the United States, normal pension ages are currently increasing. The normal pension age was 65 for those born up to 1938. It then began increasing by two months per year, a process what will come to a temporary halt with the cohort born in 1943, when the normal pension age will be 66. The normal pension age will increase again at the rate of two months per year beginning with those born in 1956 and will stop with those born in 1960 at a constant normal pension age of 67 . According to the German pension age reform, people born in 1964 and thereafter would have a constant pension age of 67 .

\section{References}

AARP Global Aging Program. n.d. Politics and Aging Fact Sheet. «http://assets.aarp.org/www. aarp.org_/articles/international/AARP_graphs_l.pdf» .

Bergstrom, Ted C. and John Hartman. 2005. Demographics and the Political Stability of Pay-asyou-go Social Security. Available at "http://repositories.cdlib.org/cgi/viewcontent.cgi?arti cle $=1188$ c context=ucsbecon" .

Demeny, Paul. 1986. "Pronatalist policies in low-fertility countries: Patterns, performance, and prospects," Population and Development Review 12 (Supplement): 335-358.

Deutscher Bundestag. 2004. Stenografischer Bericht, 102 Sitzung. (Plenarprotokoll 15/102): 9269-9280. Available at "http://dip.bundestag.de/btp/15/15102.pdf».

Disney, Richard. 2007. " Population ageing and the size of the welfare state: Is there a puzzle to explain?," European Journal of Political Economy 23(2): 542-553. Available at "http://www. nottingham.ac.uk/economics/cpe/publications/Disney_2006_welfare_state_size.pdf».

Foreign Press Center Japan. n.d. Japan: A Web Guide. Available at "http://fpcj.jp/old/e/mres/ publication/jp/society/social_main.html".

Holtzmann, Robert and Edward Palmer. 2006. Pension Reform: Issues and Prospects for Non-Financial Defined Contribution (NDC) Schemes. Washington, DC: The World Bank. 
Hurd, Michael D. and Kathleen McGarry. 1995. "Evaluation of subjective probabilities of survival in the Health and Retirement Study," Journal of Human Resources 30 (Supplement): S268-S292.

- 2002. "The predictive validity of subjective probabilities of survival," The Economic Journal 112: 966-985.

Lutz, Wolfgang, Warren C. Sanderson, and Sergei Scherbov, 2001. "The end of world population growth," Nature 412: 543-545.

MacManus, Susan. 1995. "Taxing and spending: A generational perspective," The Journal of Politics 57(3): 607-629.

McDonald, Michael D. and Ian Budge. 2005. Elections, Parties, Democracy: Conferring the Median Mandate. Oxford: Oxford University Press.

Poterba, James M. 1998. "Demographic change, intergenerational linkages, and public education," American Economic Review 88(2): 315-320.

Preston, Samuel. 1984. "Children and the elderly: Divergent paths for America's dependents," Demography 21 (4): 435-457.

Sakamoto, Junico. 2005. Japan's Pension Reform. SP Discussion Paper 0541. Washington, DC: The World Bank. «http://unpanl.un.org/intradoc/groups/public/documents/APCITY/UNPAN024379.pdf".

Salm, Martin. 2006. "Can subjective mortality expectations and stated preferences explain varying consumption and saving behaviors among the elderly?," Mannheim Research Institute for the Economics of Aging Working Papers 111-2006.

Sanderson, Warren C., and Sergei Scherbov. 2005. "Average remaining lifetimes can increase as human populations age," Nature 435: 811-813.

. 2007. "A new perspective on population aging," Demographic Research 16(2): 27-58:

Sinn, Hans-Werner and Silke Uebelmesser. 2003. "Pensions and the path to gerontocracy in Germany," European Journal of Political Economy 19(1): 153-158.

Statistisches Bundesamt Deutschland. 2003. Wirtschaft und Statistic 3: 171-188 Available at "http://www.bundeswahlleiter.de/wahlen/download/waehlerverhalten.pd".

Uebelmesser, Silke. 2004. "Political feasibility of pension reforms," Topics in Economic Analysis and Policy Vol. 4: Iss. 1, Article 20. Available at "http://www.bepress.com/bejeap/topics/ vol4/issl/art20".

United States Census Bureau. 2006. "Voting and registration in the election of November 2004," Current Population Reports P20-556.

United States Social Security Administration. 2004. Retirement Benefits (SSA Publication No. 05-10035). Available at "http://www.ssa.gov/pubs/10035.pdf».

_. 2007. "Recent developments in foreign public and private pensions," International Update, May. «http://www.ssa.gov/policy/docs/progdesc/intl_update/2007-05/2007. 05.html".

Weimann, Mike. 2002. Wahlrecht für Kinder: Eine Streitschrift. Weinheim: Beltz. 